THE LAMAR SERIES IN WESTERN HISTORY

The Lamar Series in Western History includes scholarly books of general public interest that enhance the understanding of human affairs in the American West and contribute to a wider understanding of the West's significance in the political, social, and cultural life of America. Comprising works of the highest quality, the series aims to increase the range and vitality of Western American history, focusing on frontier places and people, Indian and ethnic communities, the urban West and the environment, and the art and illustrated history of the American West.

E D I T O R I A L B O A R D

Howard R. Lamar, Sterling Professor of History Emeritus, Past President of Yale University

William J. Cronon, University of Wisconsin-Madison Philip J. Deloria, University of Michigan

John Mack Faragher, Yale University Jay Gitlin, Yale University

George A. Miles, Beinecke Library, Yale University

Martha A. Sandweiss, Amherst College

Virginia J. Scharff, University of New Mexico

Robert M. Utley, Former Chief Historian, National Park Service

David J. Weber, Southern Methodist University 
War of a Thousand Deserts: Indian Raids and the U.S.-Mexican War, by Brian DeLay

The Comanche Empire, by Pekka Hämäläinen Frontiers: A Short History of the American West, by Robert V. Hine and John Mack Faragher Bordertown: The Odyssey of an American Place, by Benjamin Heber Johnson and Jeffrey Gusky Emerald City: An Environmental History of Seattle, by Matthew Klingle Making Indian Law: The Hualapai Land Case and the Birth of Ethnohistory, by Christian W. McMillen

The American Far West in the Twentieth Century, by Earl Pomeroy Fugitive Landscapes: The Forgotten History of the U.S.-Mexico Borderlands, by Samuel Truett

Bárbaros: Spaniards and Their Savages in the Age of Enlightenment, by David J. Weber

F O R T H C O M I N G T I T L E S

The Bourgeois Frontier, by Jay Gitlin

Defying the Odds: One California Tribe's Struggle for Sovereignty in Three Centuries, by Carole Goldberg and Gelya Frank

Under the Tonto Rim: Honor, Conscience, and Culture in the West, I880-1930, by Daniel Herman

William Clark's World: Describing America in an Age of Unknowns, by Peter Kastor César Chávez, by Stephen J. Pitti Geronimo, by Robert Utley 
To view this image, please refer to the print version of this book. 


\section{The Spanish Frontier in North America}

THE B RIEF E D T IO N

\section{David J. Weber}

YA L E U N I V E R S I T Y P R E S S

NEW HAVEN A N D L O N D N 
Copyright (C) 2009 by Yale University. All rights reserved. This book may not be reproduced, in whole or in part, including illustrations, in any form (beyond that copying permitted by Sections I07 and Io8 of the U.S. Copyright Law and except by reviewers for the public press), without written permission from the publishers.

Designed by Nancy Ovedovitz and set in Adobe Caslon type by Binghamton Valley Composition, Binghamton, New York. Printed in the United States of America by Sheridan Books, Ann Arbor, Michigan.

Library of Congress Cataloging-in-Publication Data

Weber, David J.

The Spanish frontier in North America / David J. Weber. The brief ed.

$$
\text { p. } \mathrm{cm} \text {. }
$$

Includes bibliographical references and index. ISBN: 978-0-300-I4068-2 (alk. paper)

I. Southwest, New-History-To I848. 2. Southern StatesHistory-Colonial period, ca. I60o-I775. 3. SpaniardsSouthwest, New-History. 4. Spaniards-Southern StatesHistory. 5. Frontier and pioneer life-Southwest, New. 6. Frontier and pioneer life-Southern States. I. Title. $\mathrm{F}_{799 .} \mathrm{W}_{42} 2009$ $975^{\prime} \cdot 02-\mathrm{dc} 22$ 20080263 I6

A catalogue record for this book is available from the British Library.

This paper meets the requirements of ANSI/NISO Z39.48-1992 (Permanence of Paper). It contains 30 percent postconsumer waste (PCW) and is certified by the Forest Stewardship Council (FSC).

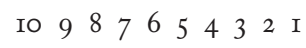

Frontispiece: A detail from William H. Powell's romantic oil painting The Discovery of the Mississippi by De Soto, I54I (I2' x I8'), commissioned in 1847 for the rotunda in the U.S. Capitol, where it hangs yet today. Courtesy of the Architect of the U.S. Capitol. 
Compadre, I entreat you to do me the favor of taking my son Antonio among your troops, that when he is old, he may have a tale to tell. Fulano de Escobedo to Alonso de León, Coahuila, ca. I69o 
This page intentionally left blank 